UDC 612.017.1

\title{
BORN IN UKRAINE: NOBEL PRIZE WINNERS ILYA MECHNIKOV, SELMAN WAKSMAN, ROALD HOFFMANN AND GEORGES CHARPAK
}

\author{
T. V. DANYLOVA ${ }^{1 \bowtie}$, S. V. KOMISARENKO² \\ ${ }^{1}$ National University of Life and Environmental Sciences of Ukraine, Kyiv; \\ 凶e-mail: danilova_tv@ukr.net; \\ ${ }^{2}$ Palladin Institute of Biochemistry, National Academy of Sciences of Ukraine, Kyiv; \\ e-mail:svk@biochem.kiev.ua
}

Received: 18 February 2019; Accepted: 14 March 2019

\begin{abstract}
Our country has not yet gained recognition from a Nobel Committee, however, some Nobel Prize winners were born in the territory, which belongs to present-day Ukraine. Among them are the father of innate cellular immunity Ilya Mechnikov; the famous microbiologist and biochemist Selman Waksman, whose studies had led to the discovery of streptomycin; the outstanding chemist, poet and playwright Roald Hoffmann, and the prominent physicist Georges Charpak who invented and developed particle detectors, in particular, the multiwire proportional chamber. This paper aims to outline briefly the main stages of their scientific activity.
\end{abstract}

Ke ywords: The Nobel Prize, Ukraine, phagocytosis, immunity, streptomycin, the electronic structure of molecules, the organic reactions, multiwire chamber.

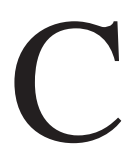
ontemporary science is to be understood within a new perspective of the multidimensional vision of its history. History of science is a colorful spectrum of the options for the development of humanity. Each of them has its advantages and disadvantages, and none is perfect. The history of science is not just a ladder that let humanity go up, but shining peaks of a mountain chain that complement each other and form a magnificent panorama. The outstanding achievements in science win the most prestigious science award - The Nobel Prize in Physics, Chemistry, Physiology or Medicine, Literature, and for Peace [1, 2]. The Prize in Economic Sciences in memory of Alfred Nobel was established by Sweden's central bank in 1968. 908 Laureates and 27 organizations have been awarded the Nobel Prize between 1901 and 2018 [3], and none of them was a representative of Ukrainian science. However, the land of Ukraine gave the world a constellation of Nobel Prize winners who revealed their great potential in the other countries.

\section{Ilya Mechnikov}

Ilya Ilich Mechnikov, or Élie Metchnikoff (1845-1916) - an outstanding microbiologist, cytologist, embryologist, immunologist, physiologist, and pathologist. He was born in the village of Ivanovka, not far from Kharkov (present-day Ukraine), in the family of Ilya Ivanovich Mechnikov, the retired officer and land-owner, and Emilia Lvovna (née Nevahnovich), the daughter of the famous Jewish publicist and enlightener Leo Nikolaevich Nevahovich (Yehuda Leib ben Noach).

Ilya's mother encouraged him to pursue a scientific career in the field of life sciences. In 1856, Ilya Mechnikov enrolled at the Lycée Kharkov. Here at the age of fifteen, he first encountered a microscope and started studying cells and structure of tissues. In 1863, Ilya became a student of the University of Kharkov. Completing a four-year course in two years, he continued his education in Germany and Italy.

(C) 2019 Danylova T. V., Komisarenko S. V. This is an open-access article distributed under the terms of the Creative Commons Attribution License, which permits unrestricted use, distribution, and reproduction in any medium, provided the original author and source are credited. 


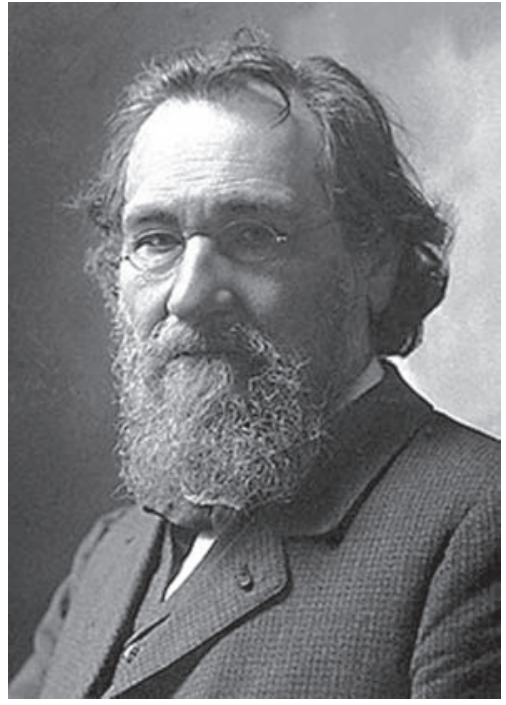

Ilya Mechnikov

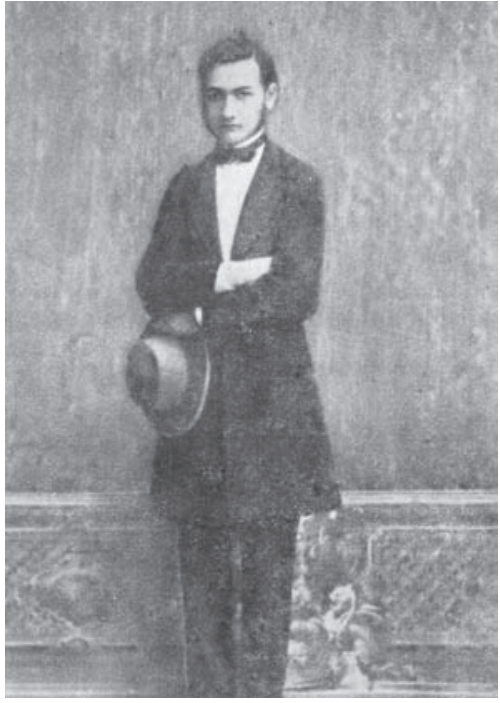

Ilya Mechnikov

(Photo from the Nobel Foundation archive)

In Giessen (Germany) he made his first scientific discovery on the intracellular digestion of flatworms. Exploring the development of invertebrate model organisms, Ilya Mechnikov tried to shed light on the origin of multicellular organisms and the mechanisms of tissue differentiation. He established a new field of science known as comparative embryology.

In 1867, Ilya earned his doctorate and both with his friend Alexander Kovalevsky shared the first Karl Ernst von Baer Prize [4]. Mechnikov was appointed Associate Professor at Odessa University. After a conflict with his colleagues, he had left to St. Petersburg, but in 1870 he returned back to Odessa as a Titular Professor of Zoology and Comparative Anatomy [5]. In 1882 due to political turmoil in the Russian Empire, Ilya Mechnikov left the university and went to Messina (Italy), where he made the most important discovery - phagocytosis. During his further work, he proved the role of phagocytosis in protecting the body from infections [6]. He was not the first to observe the process of phagocytosis, however, he was the first to state that phagocytosis served as a natural immune system.

In 1885 , a scientist returned to Odessa where he stayed for one year. Then he left his homeland forever - he went to Paris where he headed the Department of Comparative Morphology of Microorganisms at the Pasteur Institute. Later he became a Deputy Director of this famous foundation. "During his years at the Pasteur Institute, Mechnikov authored treatises on the topics of senescence, disease, and death. In his 1903 Études sur la nature humaine: Essai de philosophie optimiste (The Nature of Man: Studies in Optimistic Philosophy), he argued that science, rather than religion or philosophy, can lead to meaningful optimism, despite the apparent disharmony between humans and their environment. According to Mechnikov, science could, and would continue to, suppress disease and regulate proper hygiene, thereby contributing to the progress of civilization” [5].

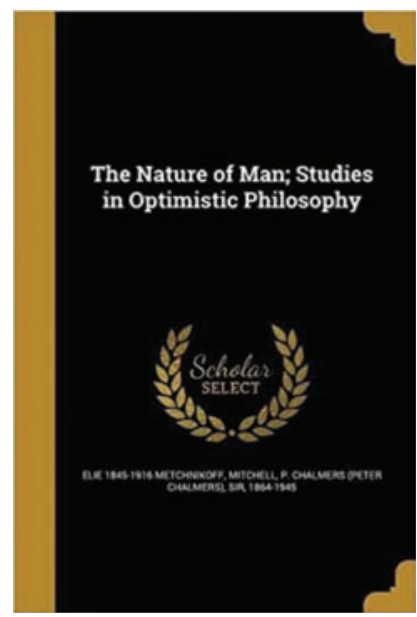

For Ilya Mechnikov, France became the second motherland. In 1908, he was awarded, together with Paul Ehrlich, the Nobel Prize in Physiology or Medicine "in recognition of their work on immunity" [7].

Ilya Mechnikov is considered the father of innate cellular immunity. The prominent scientist received an honorary degree from the University of Cambridge and the Copley Medal of the Royal Society. He had honorary memberships in the 
Academy of Medicine in Paris and the Academy of Sciences and Medicine in St. Petersburg [5].

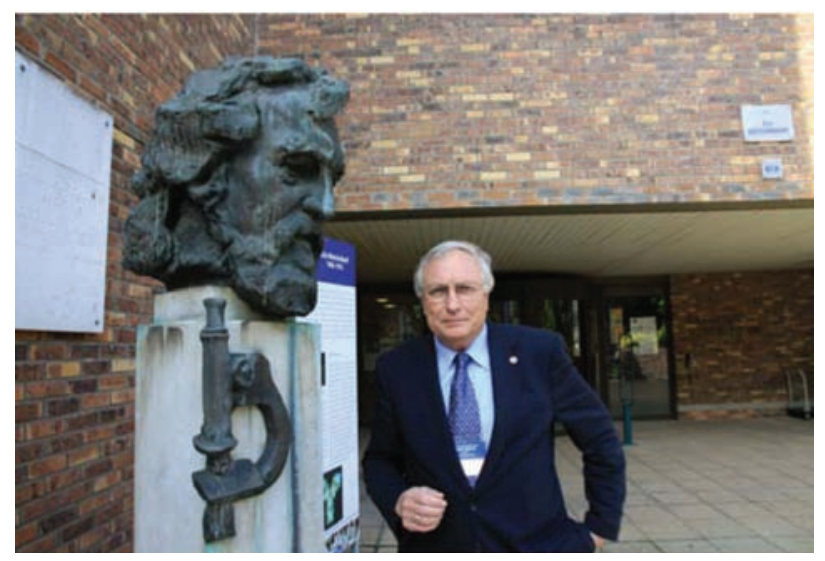

In 1986 on behalf of the Academy of Sciences of Ukrainian Soviet Socialist Republic, the monument to I. Mechnikov was installed in front of the Department of Immunology named after I. Mechnikov at the Pasteur Institute, Paris, France. This monument was inspired by Prof. S. Komisarenko and created by a famous Ukrainian sculptor V. Znoba.

\section{Selman Waksman}

The other prominent scientist - microbiologist and biochemist Selman Abraham Waksman (18881972) - was born and raised in the rural town of Novaya Priluka (present-day Ukraine). The fertile soil of his region inspired his thought, and this curiosity had a great impact on his future field of research [8]. He was the only child of Fradia London, a textile

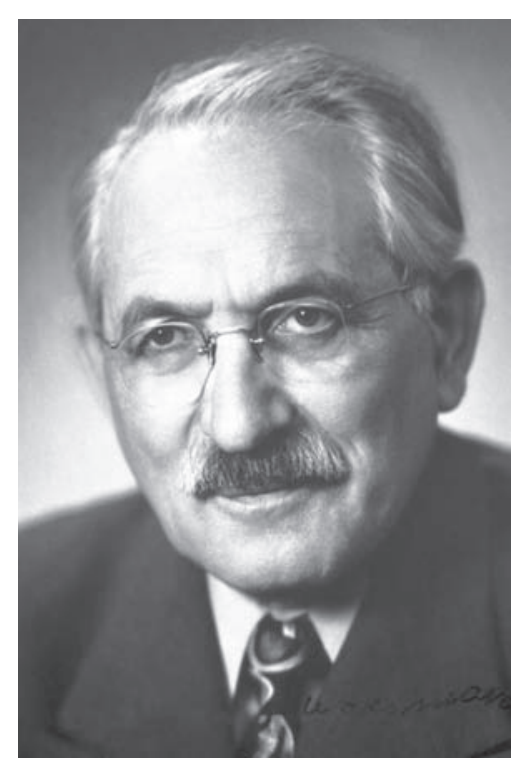

Selman Waksman

(Photo from the Nobel Foundation archive) merchant, and a former soldier and landlord Jacob Waksman. His family was Jewish, so his early education was of religious nature: Selman studied the Jewish texts and history. Growing older, he became less interested in religion. In 1910, he obtained his matriculation diploma from the Fifth Gymnasium in Odessa. However, he was faced with the problem of quotas on the number of Jewish students into universities. Following some of his relatives, he migrated to the United States where he enrolled at Rutgers College. In 1916 after performing research in soil bacteriology at the New Jersey Agricultural Experiment Station, he was awarded M.Sc. degree. This year he was appointed a Research Fellow at the University of California. The move to California was also his wedding trip: he married to Deborah Mitnik, a vocalist and artist from his hometown and the future mother of his son Byron Halsted Waksman - an American neuroimmunologist, experimental pathologist, educator, and medical association administrator who was born in 1919. In 1918, Selman Waksman earned his Doctor of Philosophy Degree in Biochemistry. He joined the faculty at Rutgers University (the Department of Biochemistry and Microbiology).

In 1925, he was appointed Associate Professor and in 1930 - Professor. In 1940, he headed the Department of Microbiology. He became Director of the Institute of Microbiology in 1949 [9, 10].

In 1923, Selman Waksman and his student Robert Starkey discovered that actinomycetes colonies growing in soil killed many common soil bacteria [11]. Inspired by the discovery of Rene Dubois

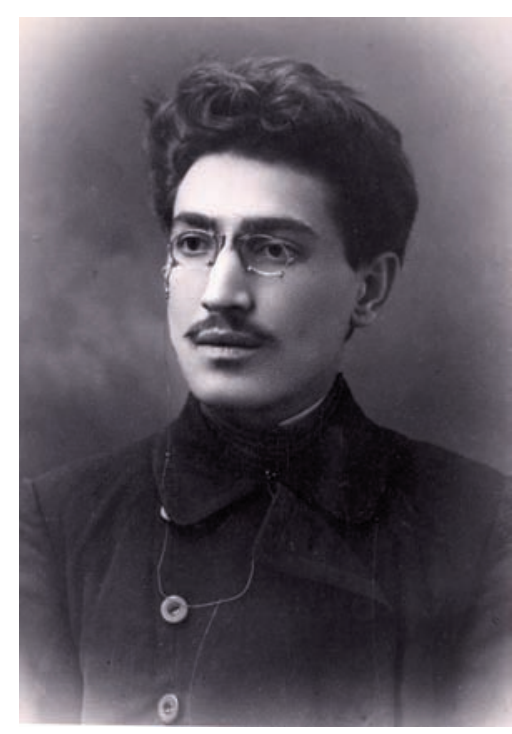

Selman Waksman [9] 
and Oswald Avery who isolated a soil bacterium that could attack the capsular polysaccharide of Streptococcus pneumoniae, Waksman started searching for more antibacterial organisms in soil samples [8]. Waksman's team discovered four bacteria-killing chemicals: actinomycin, clavacin, fumigacin, and streptothricin [12]. Unfortunately, all appeared to be toxic to animals and thus of little therapeutic value. Later, he identified more than 20 new natural inhibitory substances, including streptomycin and neomycin. It was Selman Waksman who coined the word "antibiotic" to describe them.

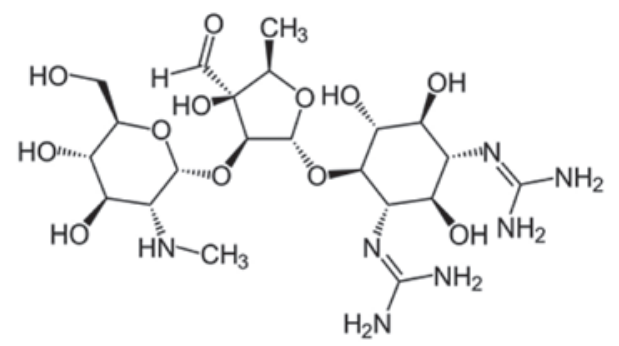

\section{Streptomycin}

In 1952, Selman Abraham Waksman was awarded the Nobel Prize in Physiology or Medicine "for his discovery of streptomycin, the first antibiotic effective against tuberculosis" [14].

An American biochemist R. D. Hotchkiss in his biographical memoir "Selman Abraham Waksman (1888-1973)" stated: "For Waksman the discovery of streptomycin in 1944 and its effect on the tubercle bacillus accomplished with the collaboration of A. Schatz and confirmation by E. Bugie was a rich and satisfying fulfillment of many of his personal and altruistic aims. Ever practical, he established effective and congenial relations with Merck and Company, which developed liquid culture methods for production of bulk quantities of the microbial products during World War II. Patenting and licensing the promising ones, notably streptomycin, provided funds, 80 percent of which was assigned to Rutgers University to support research and eventually an associated Institute of Microbiology. He also soon arranged to have animal tests and clinical trials carried out at the Mayo Clinic to expedite the possible use in treating tuberculosis. Of the 20 percent of license funds accruing in his own name, one half was later consigned to a foundation for research support” [13, p. 9].

For his tremendous work, Selman Waksman received the Albert Lasker Award for Basic Medical Research (1948), French Legion Honor (1950), Leeu-

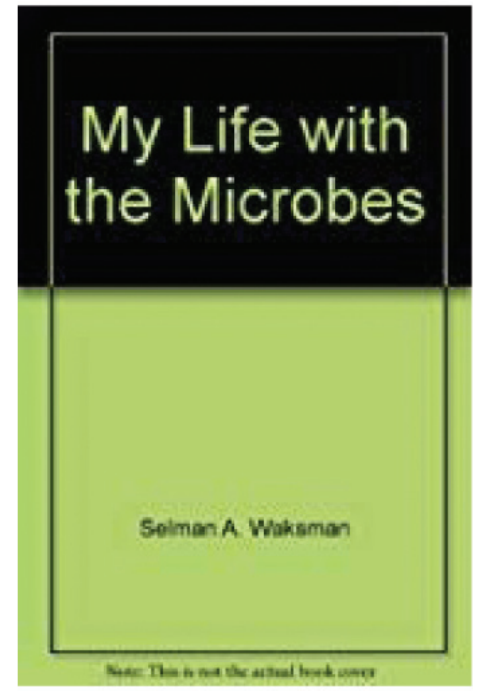

wenhoek Medal (1950). Since 1968, every two years, the National Academy of Sciences has awarded the Selman A. Waksman Award in Microbiology for "excellence in the field of microbiology" [12].

Selman Waksman always remembered his hometown in Ukraine. Travelling with his wife in Europe in 1924, they were welcomed to visit their native Ukraine. They were shocked at a depressing decay in conditions there. In five years, they visited Novaya Priluka together with their son.

Selman Waksman - Father of Antibiotics - died in 1973 in Woods Hole, Massachusetts.

Selman Waksman was an extraordinary scholar - he was the author and coauthor of over 400 scientific papers and 28 books, among which is his autobiography "My Life with the Microbes".

\section{Roald Hoffmann}

The fate of Roald Hoffmann (born 1937) the Nobel Prize winner in Chemistry - is amazing. Hoffmann (birth name - Roald Safran) was born in Złoczów, Poland (now Zolochiv, Lviv region, present-day Ukraine) in the Jewish family. His mother Clara Safran (née Rosen) was a teacher and his father Hillel Safran was a civil engineer graduated from Lviv (Lemberg) Polytechnic.

During World War II, Hoffmann's family was placed in a labor camp. As many prisoners were transferred to extermination camps, Roald's father helped him and his mother to escape from the camp. Together with three family members, they found a shelter in the Ukrainian village of Univ. Ukrainian teacher Mykola Dyuk and his wife Maria hid them in the school attic, where they remained for fifteen 


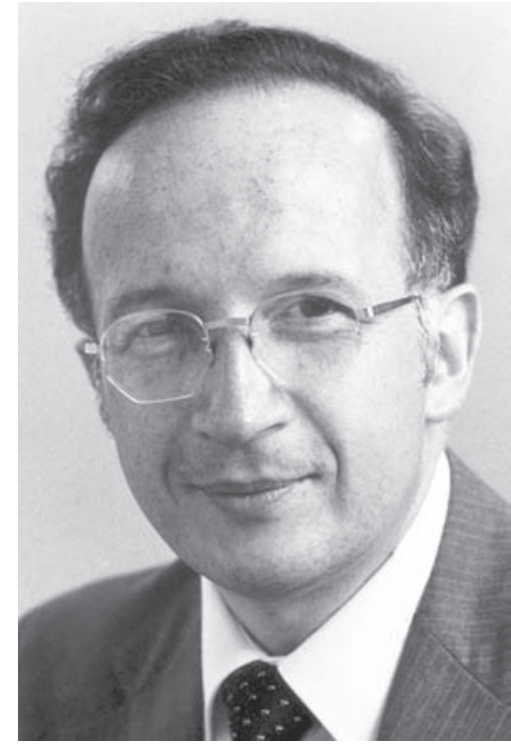

Roald Hoffmann

(Photo from the Nobel Foundation archive)

months. As Hoffman stated, the Dyuk family saved them at the incredible risks to their lives [15]. Contact with the Dyuk family was maintained over the years.

Many years later, Roald Hoffmann said, "I am very happy to have been born in the Ukraine. If I had remained, it could be that I would be a very good psychiatrist... It was not my fate. I am here. I am not unhappy... I have had a good career. I have a good family. I am happy. I am eternally grateful to the Dyuk family because I would not be here, because if it were not for the good deeds of Mykola and Maria Dyuk" [15]. In 2007, Roald Hoffman and his sister Elinor turned to Yad Vashem and asked to recognize
Mykola and Maria Dyuk as Righteous Among the Nations and on September 23, 2007, "the commission for the Designation of the Righteous conferred upon Mykola and Maria Dyuk the title of the Righteous Among the Nations" [17].

In 1944, Red Army liberated the prisoners from the camps. Roald and his family moved to Krakow (Poland), where the boy started attending school. His mother married Paul Hoffmann who became a very good step-father to Roald. In 1949, they relocated to the United States of America.

In 1955, Roald graduated from Stuyvesant High School, became a U.S. citizen and took his stepfather's last name. He enrolled at Columbia University in New York City in 1955. In 1958, Roald Hoffmann received his Bachelor of Arts Degree in Chemistry at Columbia College, in 1960 - Master of Arts Degree in Physics, and his Doctor of Philosophy Degree in Chemical Physics in 1962, both from Harvard University [18].

In 1960, he married Eva Börjesson whom he met attending a summer program in quantum chemistry at the University of Uppsala in Sweden. They had two children - a son, Hillel Jan, and a daughter, Ingrid Helena.

Hoffmann continued research in applied theoretical chemistry at Harvard. In 1964, he began to work with Robert Burns Woodward. Accepting a position as Associate Professor of Chemistry at Cornell University in Ithaca, New York, in 1965, he continued his work with Woodward. They discovered that many reactions involving the formation or breaking of rings of atoms take courses that depend on an identifiable symmetry in the mathematical descrip-
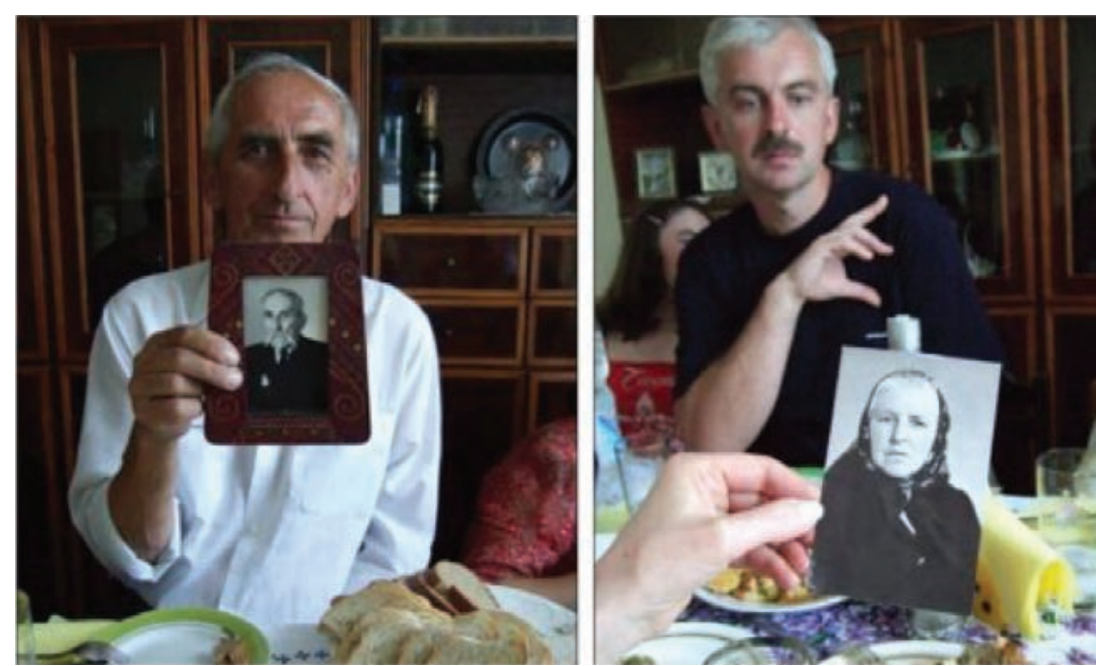

Photos of Mykola and Maria Dyuk (Personal archive of Prof. R. Hoffman) [16] 
tions of the molecular orbitals that undergo the most change [19, 20]. They formulated the WoodwardHoffmann rule describing the principle of preserving orbital symmetry in synchronic reactions. In 1968, Hoffmann was promoted to Full Professor at Cornell. From 1974 to 1996 he was John A. Newman Professor of Physical Sciences.

In 1981, Roald Hoffmann received the Nobel Prize in Chemistry, which he shared with Kenichi Fukui - a Japanese chemist - "for their theories, developed independently, concerning the course of chemical reactions”. Independently of one another, Roald Hoffmann and Kenichi Fukui demonstrated how the symmetrical properties of electron orbitals explain the course of chemical reactions [21].

Roald Hoffmann summarized his contribution to science: "My first major contribution was the development of the extended Huckel method, a molecular orbital scheme which allowed the calculation of the approximate sigma- and pie- electronic structure of molecules, and which gave reasonable predictions of molecular conformations and simple potential surfaces... My second major contribution was a two-pronged exploration of the electronic structure of transition states and intermediates in organic reactions" [22].

Roald Hoffmann has received many awards and distinctions, including Priestley Medal; Arthur C. Cope Award in Organic Chemistry; Organic Chemistry Award (American Chemical Society), 1969; Inorganic Chemistry Award (American Chemical Society), 1982; Pimentel Award in Chemical Education (1996); Award in Pure Chemistry; Monsanto Award; National Medal of Science; National Academy of Sciences; American Academy of Arts and Sciences Fellow; American Philosophical Society Fellow; Foreign Member, Royal Society; Member of the Royal Swedish Academy of Sciences; Harvard Centennial Medalist; James T. Grady-James H. Stack Award for Interpreting Chemistry [23].

Hoffmann's interests are more than just pure science. As he emphasizes, the world of the arts and literature just opened up to him in his college days [24].

He is also a writer, "carving out for himself a land between poetry, philosophy and science" [18]. He has written about a wide variety of topics, such as chemistry's relationship to philosophy, literature, and the arts, including the nature of chemical reasoning, the role of symbolism and writing in science, and the relationship between art, craft, and science [25, 26]. Since 1996, Roald Hoffman is a Frank H.T. Rhodes Professor of Humane Letters, Emeritus at Cornell University. His interest in poetry was stimulated by Mark Van Doren at Columbia. He is the author of "The Metamict State" (1987); "Gaps and Verges" (1990); "Memory Effects" (1999); "Soliton" (2002); "Catalista: Poemas Escogidos" (2002), "Roald Hoffmann. Izbrannie Stichotvorenia" (2010) [27]. He has also co-written a play entitled "Oxygen", and two by himself, "Should've" and "Something that Belongs to You", which is about the Jewish family saved by the Ukrainian family during World War II.

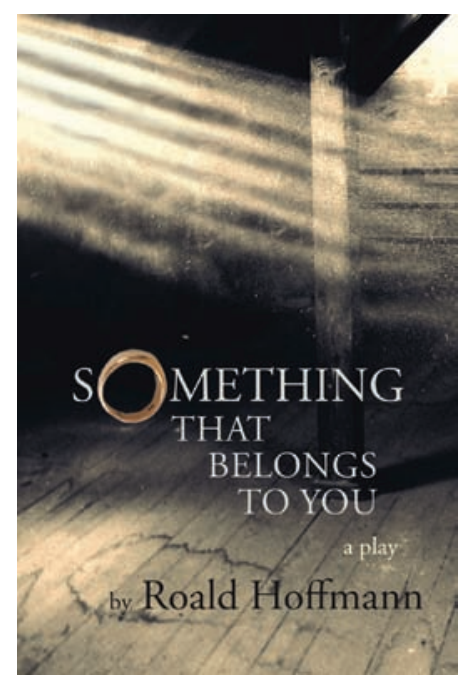

In his interview, Roald Hoffmann strongly advocates for art: "We need the arts, for they address the problems that are capable of no solution, only infinite paraphrasing, infinite resolutions. There is room for the million-third poem about the end of love, for there is no strict calculus of that loss. The humanities also temper the dictates of politics and reason, they make you understand that things are never black or white, but shades of gray in which fallible men and women strive to be good to others and to themselves. Something is not right about a major university (mine!) into which there come annually 400 million dollars in federal support, of which 385 go for science and engineering, and less than 1 million for the humanities. No reason to blame the government or the university - people need to change too" [28].

In 2017, Zolochiv, the hometown of Roald Hoffman, held an event to commemorate Hoffmann's $80^{\text {th }}$ birthday. Zolochiv has named a street after him, and Ukraine issued a postage stamp on his birthday [24]. 


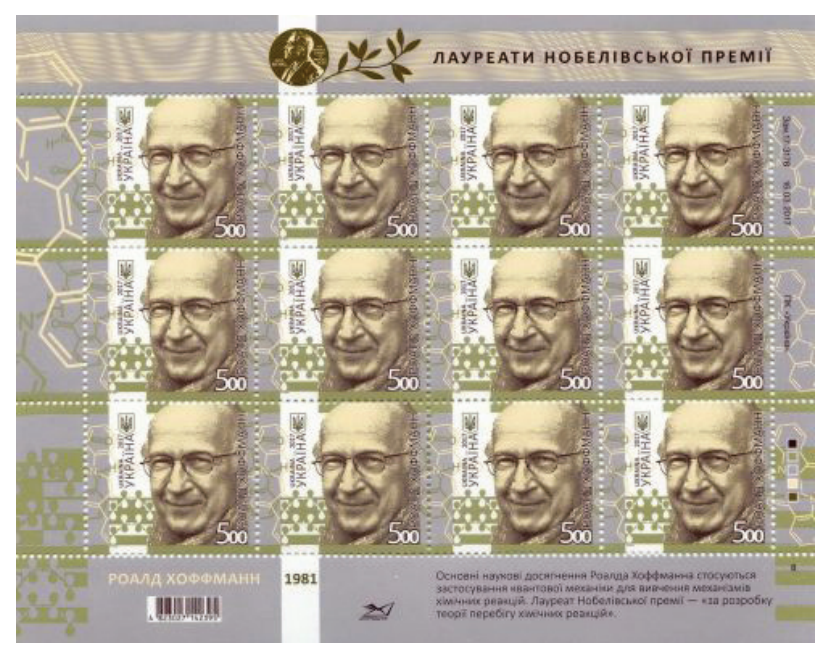

\section{Georges Charpak}

One of the most prominent scientists of our time - Georges Charpak (1924-2010) - is our fellow countryman too. He was born in Dąbrowica in Poland (now Dubrovytsia, Rivne region, present-day Ukraine) to the Jewish family of Anna (née Szapiro) and Maurice Charpak. When he was seven years old, their family moved to Paris, France. During World War II, Georges Charpak joined the French Resistance and helped French partisans. In 1943, he was imprisoned by Vichy authorities and later deported to the Nazi concentration camp in Dachau. In 1945, the camp was liberated, and the next year Georges Charpak became a French citizen.

In 1945, he enrolled at one of the most prestigious engineering schools in France - École des
Mines, from which he graduated in 1948 earning the Degree of Civil Engineer of Mines. Georges realized that he was interested in physics more than in engineering and in 1949 he became a pupil of Frédéric Joliot Curie at the Collège de France and obtained a research position at the National Centre for Scientific Research (CNRS). He received his Doctor of Philosophy Degree in Nuclear Physics in 1954. His thesis was on the subject of very low radiation associated with the disintegration of nuclei [30]. In 1953, Georges Charpak married Dominique Vidal, and the couple had two sons, Yves and Serge, and a daughter, Nathalie.

In 1959, Georges Charpak joined the staff of CERN in Geneva, where he focused on the development of new techniques for particle physics detectors [31]. He worked first in the Synchro-cyclotron division, then in the Nuclear Physics division (1961), and the Experimental Physics division (1976). After his retirement from CERN, he continued to work in the Particle Physics Experiment division, the Accelerator Technology division, and the Large Hadron Collider division [32]. He worked mainly on the development of new techniques for particle detection. In 1968, he built his first multiwire proportional tracking chamber. Largely due to his work, particle physicists have been able to focus their interest on very rare particle interactions, which often reveal the secrets of the inner parts of matter. His invention revolutionized particle detection bringing it into the new level - the electronic age. In his chamber, Char-

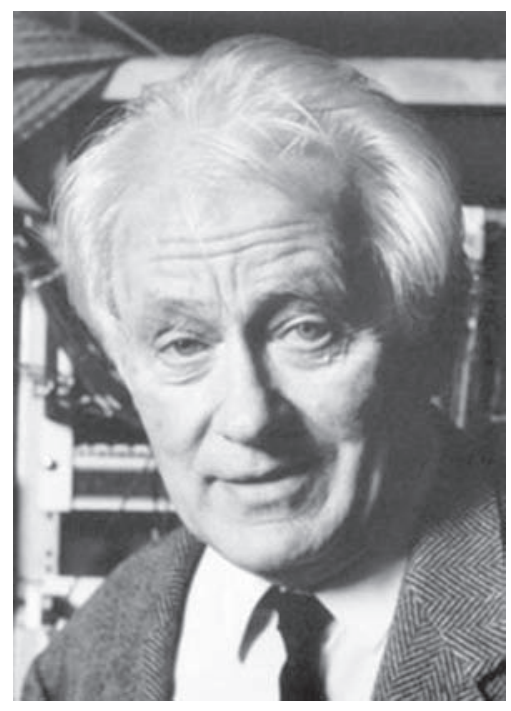

Georges Charpak

(Photo from the Nobel Foundation archive)

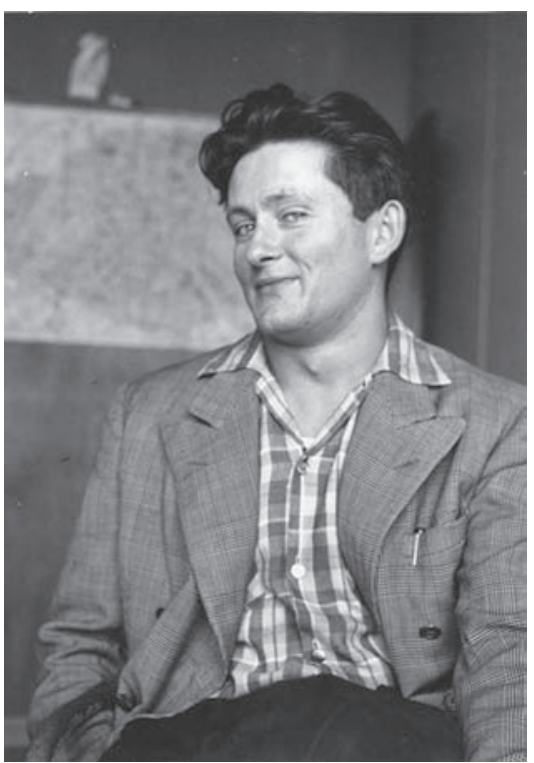

Georges Charpak [29] 
pak used modern electronics and connected the detector directly to a computer. His fundamental idea has been developed, and for many years Georges Charpak has been at the forefront of this development [33]. The speed and precision of the multiwire chamber and its descendants, the drift chamber and the time projection chamber, revolutionized highenergy physics [34]. In 1985, Charpak was elected to the French Academy of Sciences and received many honors and awards.

In 1992, he won the Nobel Prize in Physics "for his invention and development of particle detectors, in particular the multiwire proportional chamber" [36]. Georges Charpak in his Nobel Lecture emphasized that multiwire chambers "gave rise to further developments in the art of detectors, of which some are highly innovative. Most high-energy physics experiments make use of these methods, but their application has extended to widely differing fields such as biology, medicine, and industrial radiology" [37]. Indeed, physicist's work led to a significant improvement in medical radiography making it possible to reduce patients' exposure to radiation.

At the time Georges Charpak received the Nobel Prize, John Peoples Jr., then-director of the Fermi National Accelerator Laboratory in Illinois, said: "If

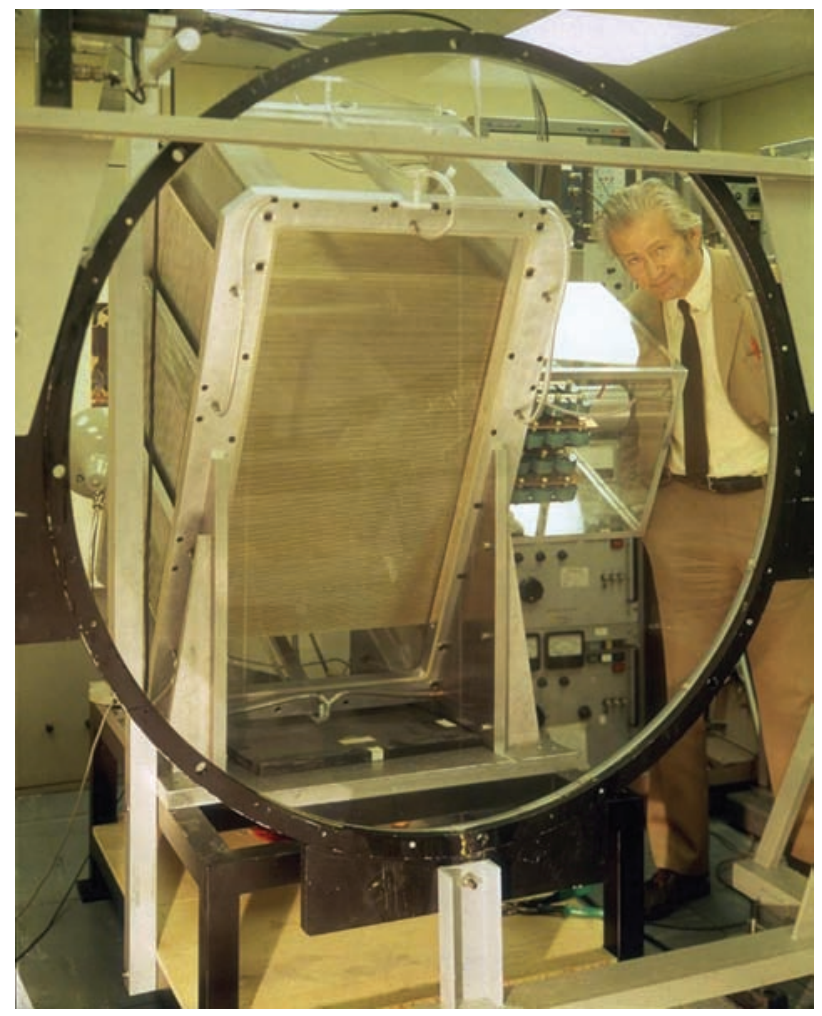

Georges Charpak and a particle detector, 1973 [35] you were to remove everything Charpak invented from all the particle detectors at all the big accelerator laboratories, you would simply not have anything left” [38].

Georges Charpak is the founder of the SOS committee at CERN, which helps those imprisoned, as he was, by repressive governments. In 2001, he received the European Grand Prix for Innovation Award in medical and biological engineering [39]. He published numerous scientific papers and books. In 2001, Georges Charpak and his co-author, American Enrico Fermi Award-winner Richard L. Garwin, analyzed nuclear issues and their potential impacts on the environment, economy, public health, and world peace in their book "Megawatts and Megatons: A Turning Point in the Nuclear Age?” [40].

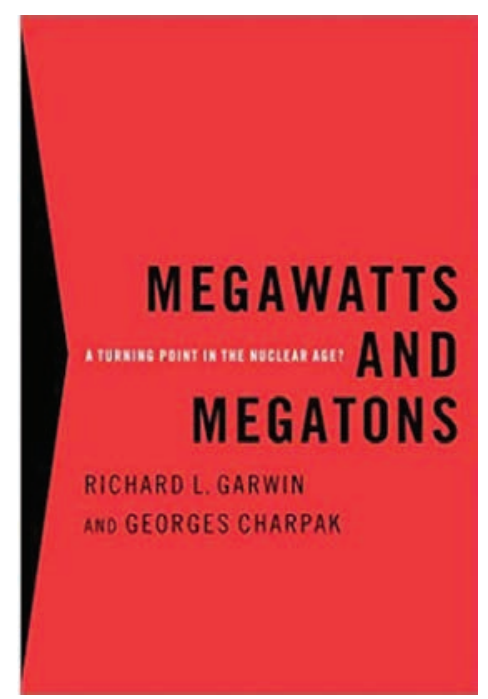

Georges Charpak was also a devoted teacher. He set up La Main à la Pâte (Hands On) movement, which promotes experimental sciences in elementary schools and encourages pupils to investigate scientific problems on a practical level. He was deeply committed to the educational process [31, 41]. Our famous fellowman Georges Charpak went down in history as a prominent physicist of the $20^{\text {th }}$ century.

Our country has not yet gained recognition from a Nobel Committee, however many Nobel Prize winners were born, began their scientific journey or worked for a while in the territory, which belongs to present-day Ukraine: Shmuel Yosef Agnon (in Literature, 1966), Svetlana Alexievich (in Literature, 2015), Simon Smith Kuznets (in Economic Sciences, 1971), Igor Tamm (in Physics, 1958), Lev Landau (in Physics, 1962). The roots of some Nobel Prize winners, who were born in the other countries, are traced back to the Ukrainian lands, which have 
always been ethnically and culturally diverse: César Milstein (in Physiology or Medicine, 1984), Eric Kandel (in Physiology or Medicine, 2000), Ralph M. Steinman (in Physiology or Medicine, 2011), Herbert Charles Brown (in Chemistry, 1979), Dan Shechtman (in Chemistry, 2011), Murray Gell-Mann (in Physics, 1969), David Jonathan Gross (in Physics, 2004), Serge Haroche (in Physics, 2012), Boris Pasternak (in Literature, 1958). A bright constellation of thinkers received the highest international distinction as the citizens of the other countries.

Unfortunately, the lack of proper conditions for scientific research, poor science funding, beggarly salaries and pensions, the lack of interest in the new investigations and projects among Ukrainian authorities and Ukrainian society make Ukrainian scientists uncompetitive on the world "scientific market”, inhibit the rise of modern science in Ukraine, cause brain drain to the highly developed countries with better living and working conditions. Today, the development of Ukrainian science, which is inextricably linked to the economic, political, social, and cultural spheres of society, should become a priority for both our state and society. It is not a private matter, but one of the most urgent problems, which can only be addressed at the state level. And then the future Ukrainian Nobel Prize winners will contribute to the world scientific and art treasury and multiply the spiritual and cultural heritage of humankind.

\section{НАРОДЖЕНІ В УКРАЇНІ ЛАУРЕАТИ НОБЕЛІВСЬКОЇ ПРЕМІЇ: ІЛЛЯ МЕЧНИКОВ, ЗЕЛЬМАН ВАКСМАН, РОАЛД ГОФФМАН І ЖОРЖ ШАРПАК}

\section{T. В. Данилова ${ }^{1 \bowtie}$, С. В. Комісаренко ${ }^{2}$}

$$
\begin{gathered}
{ }^{1} \text { Національний університет біоресурсів } \\
\text { i природокористування України, Київ; } \\
\text { e-mail: danilova_tv@ukr.net; } \\
{ }^{2} \text { Інститут біохімії ім. О. В. Палладіна } \\
\text { НАН України, Київ; } \\
\text { e-mail: svk@biochem.kiev.ua }
\end{gathered}
$$

Наша країна ще не отримала визнання від Нобелівського комітету, проте деякі лауреати Нобелівської премії народилися на території, яка належить сучасній Україні. Серед них батько клітинного вродженого імунітету Ілля Мечников; відомий мікробіолог і біохімік Зельман Ваксман, чиї дослідження привели до відкриття стрептоміцину; видатний хімік, поет і драматург Роалд Гоффман і славетний фізик Жорж Шарпак, який розробив і вдосконалив детектори елементарних частинок, зокрема багатодротову пропорційну камеру. У цій статті представлено короткий огляд основних етапів їхньої наукової діяльності.

К л ю ч о в і с ло ва: Нобелівська премія, Україна, фагоцитоз, імунітет, стрептоміцин, електронна структура молекул, органічні реакції, багатодротова камера.

\section{References}

1. Danilova VM, Vinogradova RP, Komisarenko SV. Alfred Bernhard Nobel and the Nobel Prize. Ukr Biochem J. 2018; 90(4): 121-134.

2. Danylova TV, Komisarenko SV. Scientific Investigations of the Nobel Prize Winner Emil Fischer as a Launching Pad for the Development of Biochemistry: A Brief Overview. $U k r$ Biochem J. 2018; 90(4): 135-142.

3. Nobel Prize facts. The Nobel Prize. Regime of access: https://www.nobelprize.org/prizes/facts/ nobel-prize-facts/\#note

4. Gilbert.F. (Ed.). A Conceptual History of Modern Embryology. The John Hopkins University Press, 1994. 280 p.

5. Racine V. Ilya Ilyich Mechnikov (Élie Metchnikoff) (1845 - 1916). The Embryo Project Encyclopaedia. Regime of access: https:// embryo.asu.edu/pages/ilya-ilyich-mechnikovelie-metchnikoff-1845-1916.

6. Ezepchuk YuV, Kolybo DV. Nobel Laureate Ilya Metchnikoff (1845-1916). Life Story and Scientific Heritage. Ukr Biochem J. 2016; 88(6): 98-109.

7. Ilya Mechnikov. Facts. The Nobel Prize. Regime of access: https://www.nobelprize.org/prizes/ medicine/1908/mechnikov/facts/

8. Kresge N, Simoni RD, Hill RL. Selman Waksman: the father of Antibiotics. Journal of Biological Chemistry. 2004. Regime of access: http://www.jbc.org/lens/jbc/279/48/e7

9. Selman Waksman and Antibiotics. National Historic Chemical Landmark. American Chemical Society. Regime of access: https:// www.acs.org/content/acs/en/education/ whatischemistry/landmarks/selmanwaksman. html 
10. Selman Waksman (1888-1973). Jewish Virtual Library. Regime of access: https://www. jewishvirtuallibrary.org/selman-waksman

11. Waksman SA, Starkey RL. Partial Sterilization of Soil, Microbiological Activities and Soil Fertility. Soil Science. 1923; 16(4): 247-268.

12. Selman Waksman. Famous Scientists. The Art of Genius. Regime of access: https://www. famousscientists.org/selman-waksman/

13. Hotchkiss RD. Biographical memoir of Selman Abraham Waksman. Biographical memoirs. Vol. 83, National Academy Press, Washington, D. C., 2003. Regime of access: http://www.nasonline. org/publications/biographical-memoirs/memoirpdfs/waksman-selman-a.pdf

14. The Nobel Prize in Physiology or Medicine 1952. The Nobel Prize. Regime of access: https://www. nobelprize.org/prizes/medicine/1952/summary/.

15. Saved by A Ukrainian Family, Jewish Boy Lived to Become a Nobel Laureate. YouTube. Regime of access: https://www.youtube.com/ watch?v $=y$ EhhNs1hyms

16. Kresy PL. Regime of access: https://kresy. $\mathrm{pl} /$ wydarzenia/zydowski-noblista-ukrainapowinna-przyznac-ze-upa-mordowalapolakow-i-zydow/

17. Dyuk Family. The Righteous Among the Nations. YAD VASHEM. Regime of access: http://db.yadvashem.org/righteous/family. html? language $=$ en\&itemId $=6601540$

18. Roald Hoffmann. Long Biography. Roald Hoffmann. Regime of access: http://www. roaldhoffmann.com/long-biography

19. Roald Hoffman. (1937 - ). Jewish Virtual Library. Regime of access: https://www. jewishvirtuallibrary.org/roald-hoffmann

20. Roald Hoffmann. American Chemist. Encyclopaedia Britannica. Regime of access: https://www.britannica.com/biography/RoaldHoffmann

21. Roald Hoffmann. Facts. The Nobel Prize. 1981. Regime of access: https://www.nobelprize.org/ prizes/chemistry/1981/hoffmann/facts/

22. Roald Hoffmann. Biographical. The Nobel Prize. 1981. Regime of access: https://www.nobelprize. org/prizes/chemistry/1981/hoffmann/ biographical/
23. Roald Hoffmann (Safran), Nobel Prize in Chemistry, 1981. GENi. 2018. Regime of access: https://www.geni.com/people/RoaldHoffmann-Safran-Nobel-Prize-in-Chemist ry-1981/6000000014233209639

24. Ndlovu YL. Ukrainian hometown celebrates Nobel prize-winning professor. The Department of Chemistry \& Chemical Biology. Cornell University. 2017. Regime of access: https:// chemistry.cornell.edu/news/ukrainianhometown-celebrates-nobel-prize-winningprofessor

25. Hoffmann R, Whyte IB. Beyond the Finite: The Sublime in Art and science. Oxford University Press, 2011. 208 p.

26. Kovac J, Weisberg M. Roald Hoffmann on the Philosophy, Art, and Science of Chemistry. Oxford University Press, 2012. 400 p.

27. Roald Hoffmann. Poetry Books. Roald Hoffmann. Regime of access: http://www. roaldhoffmann.com/poetry-books

28. Romanska M. Between Art and Science: A Conversation with Roald Hoffmann. Cosmopolitan Review. 2014. Vol. 6. N. 2. Regime of access: http://cosmopolitanreview. com/roald-hoffman/

29. Georges Charpak. Lycée Joffre. Regime of access: http://www.lyceejoffre.net/cpge/ blog/2010/10/15/georges-charpak-1924-2010/

30. Charpak G, Suzor F. An experimental study of the electrons of the residual atom ejected from their orbits during the disintegration of ${ }^{32} \mathrm{P}$. J Phys Radium. 1954;15(5): 378-380.

31. CNRS pays tribute to Nobel Prize Georges Charpak. Press Release. CNRS. 2010. Regime of access: http://www2.cnrs.fr/en/1789. htm?debut $=360$

32. Archives of Georges Charpak. CERN Scientific Information Service. 2011. Regime of access: http://library.cern/archives/CERN_archive/ guide/experimental_physics/division/ isacharpak

33. Georges Charpak (1924-2010). Jewish Virtual Library. Regime of access: https://www. jewishvirtuallibrary.org/georges-charpak

34. Georges Charpak. French Physicist. Encyclopaedia Britannica. Regime of access: https://www.britannica.com/biography/ Georges-Charpak 
35. CERN Library. Facebook. 2018. Regime of access: https://www.facebook.com/ CERNLibrary/posts/1968-georges-charpakinvents-the-multi-wire-proportional-chamberth rowbackthursda/10156004563326970/

36. Georges Charpak. Facts. The Nobel Prize. 1992. Regime of access: https://www.nobelprize.org/ prizes/physics/1992/charpak/facts/

37. George Charpak. Nobel Lecture. December 8, 1992. The Nobel Prize. 1992. Regime of access: https://www.nobelprize.org/prizes/physics/1992/ charpak/lecture/

38. Maugh II, T.H. Georges Charpak dies at 86; French physicist won Nobel Prize. Los Angeles
Times. October 8, 2010. Regime of access: http:// articles.latimes.com/2010/oct/08/local/la-megeorges-charpak-20101008

39. Oakes EH. Encyclopaedia of World Scientists. Infobase Publishing, 2007. 852 p.

40. Garwin RL, Charpak G. Megawatts and Megatons: A Turning Point in the Nuclear Age? Alfred A. Knopf, 2001. 412 p.

41. Close F. Georges Charpak Obituary. The Guardian. October 7, 2010. Regime of access: https://www.theguardian.com/science/2010/ oct/07/georges-charpak-obituary 